\title{
Adaptive Resilience and the Competition Between Retail and Service Agglomeration Formats: An International Perspective
}

Christoph Teller [corresponding author]

University of Surrey

Guildford, Surrey, GU2 7XH, United Kingdom.

[T] ++ 441483683981

[E] c.teller@ surrey.ac.uk

\author{
Steve Wood \\ University of Surrey \\ Guildford, Surrey, GU2 7XH, United Kingdom. \\ [T] ++ 441483683113 \\ [E] sm.wood@surrey.ac.uk
}

Arne Floh

University of Surrey

Guildford, Surrey, GU2 7XH, United Kingdom.

[T] ++ 441483689185

[E] a.floh@ surrey.ac.uk 


\title{
Adaptive Resilience and the Competition Between Retail and Service Agglomeration Formats: An International Perspective
}

\begin{abstract}
This paper investigates the competitive relationship between dominant urban agglomeration formats (traditional "evolved" town centres and "created" shopping malls) and the drivers of competiveness in the form of key agglomeration resources (accessibility, parking condition, tenant mix, atmosphere). Based on a consumer survey (n, 2,161) across three distinctive European capital cities, co-variance based structural equation modelling reveals remarkably limited differences between formats in terms of the investigated drivers of competitiveness. Positive relationships of patronage towards both formats in all cities and the significant difference in why respondents patronise them suggest a partly complementary existence of the two types of agglomeration. We explain this apparent complementarity through the theory of adaptive resilience that has seen evolved agglomeration formats develop to provide a differentiated offer and consumer attraction compared to enclosed malls.
\end{abstract}

\section{Summary Statement of Contribution}

Our theoretical and practical contributions include (1) providing a better understanding of the competition between agglomeration formats by drawing on the theory of adaptive resilience of urban places; (2) identifying the drivers of competitiveness of either agglomeration format in different urban settings. We contribute to the academic research literature within retail marketing, but more practically provide evidence that can inform the work of town centre and mall managers/marketers, retailers and mall developers.

Keywords: shopping centre, town centres, retail patronage, retail- and service network, resources, adaptive resilience

Acknowledgements: We appreciate the work of Mark Dover, Cartographic Unit, University of Southampton on the detailed maps of the three case study cities. 


\section{Introduction}

The nature of competition between retail centres and identifying drivers of their sustainability remain a key concern of social sciences research (Wrigley and Lambiri, 2014) as well as a particular challenge for retail marketing (Hart et al., 2013). This has often been framed in terms of a conflict between decentralised retailing ('out-of-town') versus established retail centres, (downtowns, high streets and town centres) (Thomas and Bromley, 2002). The US experienced these pressures from the mid-twentieth century - debates which are well known within the literature (Berry and Kasarda, 1977). Meanwhile, much of continental Europe and the UK experienced threats to established centres considerably later, particularly in the 1980 s and 1990s from large food superstores, retail parks and off-price centres that were developed away from existing towns (Thomas et al., 2004), alongside the construction of out-of-town purposebuilt enclosed shopping malls that enjoyed the added benefit of extensive car parking (Lowe, 2000). Although retail decentralisation has been slowed by land-use planning regulation, pressures from out-of-centre retailing remain a key concern for traditional centres throughout much of Europe (van der Krabben, 2009; Wood et al., 2010).

Exacerbating the pressures from decentralised retail agglomerations, traditional retail centres have recently experienced competitive forces from online channels (Weltevreden and Atzema, 2006) - challenges which were further amplified by the fallout from the wider global economic downturn and led to a marked increase in retail vacancy rates across Europe (Wrigley and Lambiri, 2014). Meanwhile, town centre managers are left to manage the image and brands of their towns (Hart et al., 2013; Warnaby et al., 2005) as they strive to establish the key drivers of footfall and determine how they can harness these to benefit their particular locales (CocaStefaniak et al., 2009). 
This paper seeks to contribute to these debates concerning the retail marketing and management factors underpinning success between agglomeration formats. We undertake an extensive consumer survey across three major capital European cities and employ structural equation modelling of the results to test a conceptual model which proposes that the core resources and capabilities of such store networks affect competitiveness, measured by the patronage intentions of consumers. Our focus is on the two most frequent agglomeration formats found in urban markets - namely 'evolved' or 'unplanned' 'urban retail and service clusters' (URSCs) ${ }^{1}$ situated within town/city centres and high streets, and 'created' or 'planned' enclosed shopping malls, typically located on the edge or out of town/city centres. The main contribution of this paper is to explore the nature and major drivers of agglomeration format competitiveness in different urban settings. By identifying the major factors affecting patronage intentions, we contribute to the academic research literature within retail marketing and management, but, more practically, provide evidence that can inform the work of town centre managers/marketers, retailers and mall developers.

The structure of this paper is as follows: Following these introductory remarks, we develop the theoretical background of this paper by drawing on research literature across retail marketing to derive hypotheses that will then be tested. The next section focuses on the methodology of the empirical study and presents the three focused case settings. Then, a description of the results and discussion of the major findings is provided. The paper closes with a critical review of the study's limitations and a future research agenda.

\footnotetext{
${ }^{1}$ This paper will use the term urban retail and service clusters (URSCs) to denote the retail agglomerations within traditional, unplanned retail centres - namely town centres and high streets
} 


\section{Theoretical background and context ${ }^{2}$}

\section{'Evolved' versus 'created' (urban) agglomeration formats}

The evolution of the modern shopping centre during the mid-twentieth century was a disruptive innovation that had far reaching effects on urban and retail structures initially of the US, and later within the UK, and across wider Europe. The original intention of Victor Gruen (19031980), who designed the first enclosed shopping malls, was to create a mirror image of a town centre under one roof and thus facilitate social interactions between residents in fast-growing and scattered American suburbs (Crawford, 1992). His buildings were meant to be more than just market places where stores would sell and consumers buy products and services; nevertheless, the retail and service components of Gruen's suburban malls made the concept so successful that he had unintentionally created, not only an efficient retail and service environment, but also an internationally successful business model (Hardwick, 2004).

Out of centre shopping mall construction challenged the downtown or city centre locations of key retail store formats such as department stores; in turn guaranteeing a flight to the suburbs and the pursuit of decentralised retailing (Longstreth, 1998). Shopping malls have become the most important retail and service agglomeration format in or close to urban retail markets (Teller, 2008), with commentators reflecting on whether they have become legitimate decentralised town/city centres in their own right (Lowe, 2000). The growing number of malls are a key explanatory factor for why evolved urban retail and service clusters (URSCs) in town/city centres have lost some of their importance as favourable locations for stores, and as

\footnotetext{
${ }^{2}$ In this section we discuss and develop the relevant theoretical background from retail marketing relating to our study. While our empirical study is situated within three major continental European cities (Vienna; Ljubljana; Bratislava), much of our conceptual framing of the study is grounded within UK and US retail contexts. We argue this is appropriate as the predominant literature concerning shopping agglomerations within the social sciences has developed within the US and UK, with comparatively little emanating from Austrian, Slovenian and Slovakian contexts. Nevertheless, we are mindful in our analysis of the variegated nature both of the geographies of these places and the possible consumer differences between the sites of study.
} 
shopping destinations for consumers across much of the western world (Dennis et al., 2005; Hughes and Jackson, 2015).

The effect of out of centre malls and retail parks on the viability and vitality of URSCs in town/city centres led to the formation of retail planning policy to protect established centres throughout much of Western Europe (Guy, 2007). Particular retail specific measures focused on directing new retail development toward evolved agglomerations in central locations and thus limit the leakage of trade to outlying decentralised sites (van der Krabben, 2009; Wood et al., 2010). More widely, public-private initiatives have emerged as policy responses across Europe particularly in the form of Business Improvement Districts (BIDS) which, imported from the US, seek to improve the attractiveness of traditional urban centres (Hart et al., 2013).

While the broad trend of high street/town centre atrophy is accurately characterised as 'from market to mall' (Haytko \& Baker, 2004, p. 68), there are more complex changes occurring that see not only retail patronage of URSCs in decline but some enclosed malls too - even within their country of origin, the United States. In 2015, nearly 15 per cent of US malls reported vacancies of 10-40 per cent - up from 5 per cent in 2006. More strikingly, 3.4 per cent are more than 40 per cent empty, which is equivalent to more than 30 million square feet (Schwartz, 2015). Such a situation contrasts markedly with the 1990s when US malls were being constructed at the rate of 140 per year (Glancey, 2014). On the one hand, these enclosed malls are under threat from so-called category killer big-box retail formats and power centres, but equally they face increasing challenges from e-tailing. Furthermore, suburban demographic shifts that had once supported their growth are now less favourable, as established centres such as downtowns and city centres undergo some degree of gentrification and residential areas neighbouring malls experience economic challenges following recession, longer term industrial shifts and - especially for some of the older suburbs - population decline (Hanlon, 2008). 
While malls and shopping centres experience their own particular challenges, it can be concluded that the competition between both agglomerations, of the same and different formats, is increasing. For managers of agglomerations, and for retail organisations operating stores within these centres, the key retail marketing questions of why consumers shop at stores in certain agglomerations, and thus what makes some agglomerations within the urban environment more competitive than others, are crucial.

\section{The nature of retail agglomerations}

Independent of the agglomeration format, the reason why retail and service organisations locate stores within agglomerations, and why consumers patronise them, lies in their generic nature as networks, which produce synergies and encourage collaborations due to the retail and service stores' close proximity to one another (Knoben and Oerlemans, 2006). The network view provides a useful vehicle for conceptualising the interplay between stores (e.g., Alexander et al., 2016); thus, it can help to identify those network resources of each specific format that might possibly create competitive advantages.

Drawing on the resource-based theory of competitive advantage (Grant, 1991), there are two drivers of competitive advantage for such networks: resources and capabilities. The competitiveness of agglomerations is based on the ability to exploit and organise resources across firms and take advantage of a retail and service location. Synergistic agglomeration effects of collaborating firms within a centre can lead to them building up competencies and acquiring resources they could not build up and acquire on their own (Duranton and Puga, 2000; Oppewal and Holyoake, 2004). Such resources can be financial (e.g. investments by the council or the shopping mall owner in refurbishing store fronts), physical (e.g. availability of managed parking spaces), human (centre management personnel), organisational (centre management/marketing organisation), technical (traffic guidance systems) or related to reputation (of the wider agglomeration) (Teller and Schnedlitz, 2012). 
One of the key resources of retail agglomerations is the proximity of stores to each other. The variation in the tenant mix of retail centres turn a collection of stores into a 'consumer habitat' (Bloch et al., 1994, p. 23) and provides opportunities for consumers to pursue mixed purpose trips on a single shopping visit (Leszczyc et al., 2004). Research has repeatedly emphasised the consumer experience of multi-purpose shopping trips to enclosed malls and urban retail centres more widely (Oppewal and Holyoake, 2004). This is an intangible and important outcome, complementing factors that make shopping in agglomerations more convenient and efficient (Arentze et al., 2005). However, the precise benefit a retailer receives from locating within an agglomeration partly depends on the nature of the service it provides and the nature of the shopping mission (Garate and Pennington-Cross, 2014).

Teller (2008) identifies different types of agglomerations - namely, (1) evolved retail and service agglomeration formats such as inner city retail clusters or high streets, (2) created retail and service agglomeration formats such as enclosed shopping malls, factory outlet centres, strip malls and other kinds of shopping centres, and (3) hybrid formats such as retail parks. Evolved retail and service agglomerations are emergent networks that are borderless, self-organising and have evolved from bilateral interactions within the network. In contrast, created agglomerations can be seen as strategic networks or value nets that contain a planned set of stores and infrastructure (Möller and Rajala, 2007). Such networks are centrally managed in order to be more efficient in creating value for their customers and owners. This higher efficiency is grounded in the fact that the capabilities of the actors behind the value creation are known, and the value creation activities and processes can therefore be managed more effectively.

Despite their considerable economic relevance in urban contexts, research has often under-emphasised the competition between, and the sources of competitiveness of, retail 
agglomerations. Retail and service research has traditionally focused on single store and shopping mall phenomena (Haytko, 2004; Pan and Zinkhan, 2006). Consequently, there is little guidance for agglomeration managers, town centre marketers or retailers operating stores in agglomerations looking to positively influence the competitiveness of their centres with respect to those of their competitors. Agglomeration managers looking for strategies to establish and maintain competitive advantage and thus facilitate long-term survival need to (1) understand their key resources and resource utilisation relative to their competitors and (2) appreciate the link between resources and capability in order to increase the effectiveness of their operations relative to those of their competitors (Grant, 1991; Lavie, 2006).

\section{Developing a conceptual model}

Measures of patronage of retail agglomerations, by their very nature, are loyalty metrics and thus key performance measures of business and business networks (Vorhies and Morgan, 2005). They are closely related to the share of visits and spending of consumers and thus directly translate into sales and profits. As such, intentional and behavioural patronage can be regarded as key measures for competitiveness in the retail and service industry (Pan and Zinkhan, 2006; Vogel et al., 2008). The literature on retail agglomerations, independent of whether it focuses on evolved or created formats, emphasise four network resources as the core drivers of patronage and thus competitiveness. Obviously, URSCs and shopping malls possess network resources in different forms and to different extents. Probably the most frequently mentioned resource (of agglomerations) that drives competitive advantage is location (Severin et al., 2001; Arentze et al., 2005). From a customer's point of view, the location determines the temporal and spatial distance between the point of purchase and the point of consumption, and thus the convenience related to accessibility. Accessibility can be operationalised by how easily and quickly consumers can reach an agglomeration, and how trouble free the journey is 
(e.g. Reimers and Clulow, 2004; Reimers and Clulow, 2004; Reimers and Clulow, 2004; Reimers and Clulow, 2004; Ruiz et al., 2004).

The attraction potential of an agglomeration usually goes beyond the average walking distance. Consumers make use of other means of transport; specifically the car in a majority of cases (Wood and Reynolds, 2013). Consequently, parking facilities become another key resource, with the organisation of parking adjacent to an agglomeration a capability (Van der Waerden et al., 1998; Reimers, 2013).

A considerable number of authors clearly see the composition of stores (tenants) within an agglomeration as driving competitiveness (Reimers and Clulow, 2004). The store mix comprises both width (complementarity) of stores and depth (choice) of similar stores. This includes realising the 'right' assortment of stores within the agglomeration which is dependent on the capability of mall management to actively create a mix according to the customers' preferences. The store mix, as such, determines the possibility of a customer satisfying their wants and needs - the generic trigger for visiting an agglomeration (Van Kenhove et al., 1999; Zhuang et al., 2006).

The final core resource, and consequently capability, of a store network is to create a favourable atmosphere for customers in the sense of a set of atmospheric cues, in particular visual, auditory and olfactory cues (Dennis et al., 2005). Atmospheric stimuli (as a resource) evolve naturally as part of the agglomeration setting, or (as a capability) can be influenced consciously by the agglomeration's management/marketing (Teller and Reutterer, 2008). Given the substantial impact of atmospheric stimuli on patronage behaviour and thus their ability to serve as a competitive advantage (Turley and Milliman, 2000; Michon et al., 2005; Teller and Dennis, 2012).

Apart from these core drivers of agglomeration patronage behaviour, the literature has investigated other factors that are quite format-specific and has found them to be of less 
relevance (Teller and Reutterer, 2008). Such factors include manoeuvrability within the agglomeration, or infrastructural services such as the provision of customer toilets, cash dispensers and recreation areas.

Regardless of the individual antecedents of patronage, the literature contends that created agglomerations such as enclosed malls are characterised by markedly different physical structures and consumption environments compared to naturally evolved URSCs such as those present within high streets and town/city centres (Teller, 2008). For example, enclosed malls are particularly noted for their accessibility and parking availability which is further supported by their typical location outside of congested city centres (Teller and Schnedlitz, 2012), meanwhile evolved centres such as high streets and town centres are not purposefully designed for automobile accessibility and therefore offer inevitable compromises in this regard (Wrigley and Lambiri, 2014). Meanwhile, within enclosed malls, the purposeful tenant mix and created consumption environment is widely noted to be powerful compared to the emergent and less directed tenant evolution evident within evolved retail destinations such as high streets and town/city centres (Teller and Reutterer, 2008; Wrigley et al., 2015). As such, the atmosphere that is likely to emerge within mall environments is likely to be more easily themed and controlled given the privatised nature of this public consumption space compared to the atmosphere consumers identify within URSCs that are often open air and typically less controlled and managed (Tsai, 2010). Given the often noted different characteristics between the two types of retail destination, we establish the following hypothesis:

$H_{m 1}$ : The impact of key agglomeration attributes on patronage is different between evolved and created agglomerations.

While we contend there are likely to be notable differences in the importance of attributes/drivers (i.e. accessibility, parking, tenant mix, atmosphere) between centres within the same agglomeration classification (e.g. mall), it is important to recognise that not all 
enclosed malls - or town centres/high streets for that matter - are characterised by the same mix of attributes and drivers and are therefore likely to be rated markedly differently by consumers (e.g. Dennis et al., 2002). Indeed, this is the very reason why some retail centres flourish, while others decline. Consequently, it is logical to develop the following two hypotheses:

$H_{m 2 a}:$ The impact of key agglomeration attributes of evolved agglomerations on patronage is different between urban settings.

$H_{m 2 b}$ : The impact of key agglomeration attributes of created agglomerations on patronage is different between urban settings.

The dynamic between evolved and created agglomerations has obvious commercial but equally considerable policy relevance. Indeed, we earlier discussed the effects of out of centre enclosed mall development across much of continental Europe in directing trade in retail and wider services away from evolved agglomerations such as town/city centres and high streets and the subsequent regulatory response via land-use planning policy aimed at limiting these trends (van der Krabben, 2009; Wood et al., 2010). Notwithstanding the influence of land-use planning regulation, enclosed mall agglomerations across much of Europe's developed economies continue to adversely affect patronage within historic, evolved centres (e.g. Thomas and Bromley, 2002). Given this apparent competition between the two forms of agglomerations, it is logical to hypothesise a negative relationship in patronage between them: $H_{3}:$ There is a negative relationship in patronage between evolved and created agglomerations.

Figure 1 therefore represents our conceptual model. 


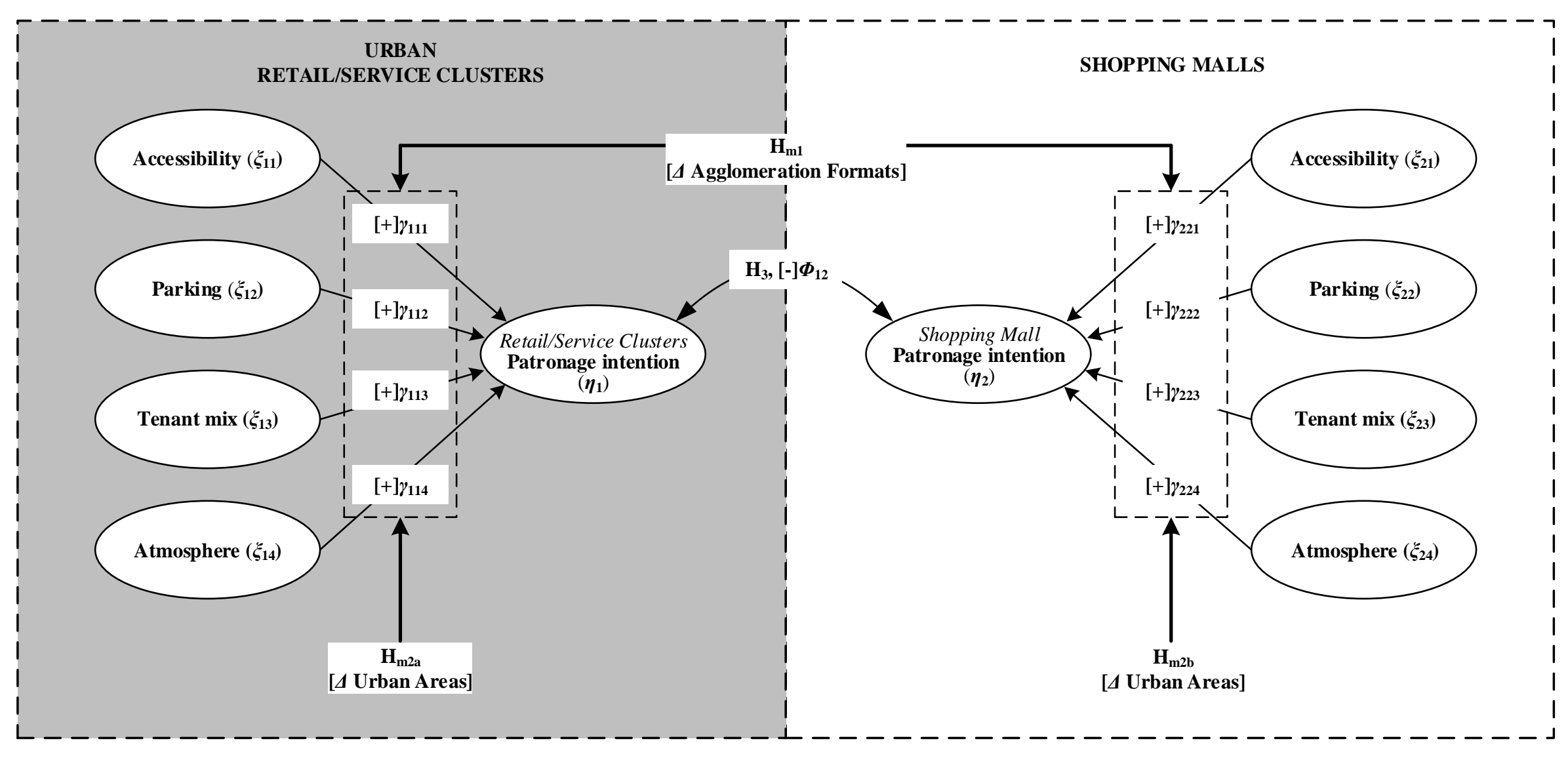

Figure 1: Conceptual Model 


\section{Methodology}

\section{Case description}

We followed the suggestion of Möller and Rajala (2007) and employed a multi-case study design, aiming to investigate differences in performance - in the sense of value creation for the consumer by comparing competing networks of different organisational structures that apply different management mechanisms. Further, we heeded the call of Severin et al. (2001) and investigated the phenomenon of agglomeration competition in an international context. We thus selected three cases that exhibited competition between URSCs and shopping malls in three urban retail markets of central European capital cities, namely Bratislava, Ljubljana and Vienna. In all three locations, the penetration of the market by shopping malls varies. Significant numbers of shopping malls have been developed since the 1970s in Vienna. Ljubljana followed suit in the 1990s, whereas Bratislava had a comparably late introduction to this agglomeration format at the beginning of the new century. All three cases are capital cities of countries that are part of the European Union, are in relatively close proximity to each other and - due to once being part of the Austro-Hungarian Empire - possess inner districts that are (despite their different sizes) very similar in terms of their structure and architecture. All three urban areas are significantly the biggest retail and service markets and considered the cultural, political and economic centres of their respective countries. While the national languages differ, the cultures (due to close proximity and common history) are arguably quite similar.

Case 1: Vienna (1.8 million inhabitants; size: $415 \mathrm{~km}^{2}$ ) represents a case where around 20 URSCs in the form of high streets compete with around 30 shopping malls. As in the other cases, it is difficult to state an exact number due to the varying definitions of URSCs and shopping malls. Although smaller high streets are losing significance to mall competition, Vienna can be seen as an example of both agglomeration types co-existing in the long term; in part due to the fact that traditional department stores on high streets have been converted into shopping malls and contribute to the attractiveness of URSCs. 
Case 2: In Ljubljana (280,000 inhabitants; size $\left.275 \mathrm{~km}^{2}\right)$, the URSCs are significantly less important due to their smaller size and number. Only around five locations, in the form of plazas or short high streets, can be classified as evolved agglomerations, and there are no dominant clusters comparable to the shopping streets in Vienna. Currently, seven created agglomerations can be identified as shopping malls in this area. From site visits, and due to the increasing number of malls, it is clear that the latter dominate the competition between the agglomeration formats in the Slovenian capital.

Case 3: In Bratislava (433,000 inhabitants; size $370 \mathrm{~km}^{2}$ ), structure and competitive situation between the agglomeration formats is similar to those in Ljubljana, and two out of four URSCs have a significant number of attractive stores and represent sets of small shopping streets and plazas. The URSCs compete with four recently built and professionally managed large shopping malls. There are further mall projects being developed, which indicates that inner city stores will come under further pressure in the near future.

\section{Survey approach}

Consistent with the focus of this paper, the units of analysis are the agglomeration formats (URSCs and shopping malls) and the competition between them. Due to their spatial proximity and comparably high share of visits, we consider the patrons of agglomerations who are permanent residents to be the population of interest, and thus the core informants regarding the competitive resources and capabilities of the different agglomeration formats. Due to the complexity and resource intensity associated with collecting data internationally, a web-based survey approach was chosen. This also allowed large samples to be reached within a limited time period (Ilieva et al., 2002), and the thoroughness of the answering process could be checked using total answer time and - in doubtful cases - recorded response behaviour online (Grant et al., 2005). We selected a sample - consumers between 16 and 60 years of age - based on quotas for gender, age and educational level. The sample units were, in all three cases, members of an online panel. The samples of 963 patrons residing in 
Vienna, 691 in Ljubljana and 514 in Bratislava represent the urban populations with respect to the imposed quotas. Due to the deliberate choice of the internet as the research medium, the data suffer a coverage bias towards younger consumers. Nevertheless, younger consumer segments represent a part of agglomerations' clientele of primary interest due to their high share of time and money spent in such agglomerations (Haytko, 2004).

In the questionnaire, the respondents had to pick their preferred shopping mall and answer questions on their patronage behaviour and the mall's attributes. Subsequently, they went through the same procedure related to their preferred URSC. Questions concerning the characteristics of the respondents concluded the survey. The questions or items operationalising the latent constructs in the model followed those used in previous research (see Appendix). Since the scales and questions were derived from publications written in English, a back-translation procedure was applied to ensure linguistic equivalence of the questionnaires in German, Slovenian and Slovak (Behling and Law, 2000). Additionally, three of focus groups were held for the purpose of item-editing. Respondents reviewed all items so that its wording would be as precise as possible and socially acceptable. By doing this, we followed the widely accepted approach by Churchill (1979).

\section{Analysis}

To test the structural effects in the model based on the data from the three settings, we applied covariance-based structural equation modelling using maximum likelihood estimation (e.g., Kaplan, 2008). As a basic prerequisite, the local fit was tested (i.e. the measurement validity), as well as the global fit of the analysed model and the degree of congruency between the proposed model and the empirical data. In line with Churchill (1979) and Bagozzi and Yi (1988), we calculated confirmatory factor analyses for each of the six models. Positive factor loadings were identified for all items, with indicator reliability greater than 0.4 and factor reliability higher than 0.6 for each of the factors (Bagozzi and Yi, 1988; Bagozzi and Baumgartner, 1994). The average variance extracted (AVE) and the Fornell-Larcker ratios (FLR) were calculated, showing how well the constructs were measured by 
their indicators (Anderson and Gerbing, 1988; Fornell and Larcker, 1981). In all cases, the recommended threshold values were met $(\mathrm{AVE}>0.5 ; \mathrm{FLR}<1)$, showing a satisfactory construct and discriminant validity (Bagozzi and Yi, 1988). Consequently, the local fit of the measurement models was regarded as satisfactory; all local fit measures are reported in the appendix. Subsequently, we tested the global fit of the proposed model with the empirical data by calculating and interpreting indices showing the absolute, incremental and parsimonious fit of each model (Anderson and Gerbing, 1988; Hu and Bentler, 1998; 1999). Table 3 shows that in all cases, the global fit is satisfactory, with all measures clearly beyond the recommended thresholds.

To test our first two hypotheses we conducted multi-group-comparison tests (e.g. Brown, 2006) which identify the moderating impact of the agglomeration format (i.e. URSC and malls) and urban areas (i.e. Vienna, Ljubljana and Bratislava) on our structural effects. More specifically, we first test for significant differences (variances) between each single factor loading of two groups and secondly each structural effect. By applying a $\chi^{2}$ difference test between the baseline model (all parameters are allowed to vary freely across the two groups) and the constrained model (an equality constraint on a factor loading or a structural effect is imposed), this test evaluated the null hypotheses that the constrained model is equal to the baseline model. Therefore, the differences of $\chi^{2}$-values $\left(\Delta \chi^{2}\right)$ of the two models were used to indicate whether the null hypotheses should be accepted or not. To test for (in-)variance between the factor loadings and thus the measurement models is seen to be a prerequisite before testing for invariance between the structural effects, i.e. our hypotheses (e.g., Hair Jr et al., 2013). To test for measurement invariance we followed the suggested procedure by Steenkamp and Baumgartner (1998). In the case the factor loadings turn out to be significantly different $\left(\Delta \chi^{2}>3.82\right.$; $d f, 1 ; \mathrm{p}<.05)$ we impose equality constraints on them and assume them to be equal in order to make the measurement models comparable. The analyses revealed partial metric invariance of our measurement instrument. In other words, the structural differences across cities and agglomeration 
formats. More details on the outcome of the $\chi^{2}$ difference test related to structural effects and thus the hypotheses testing are reported in the result section below.

\section{Results}

\section{Preferred formats and competition}

A preliminary question in the questionnaire focused on the preference of the respondents towards URSCs or shopping malls using a graphically supported 100-point rating scale. The share of preferences in the case of Vienna between the two forms of agglomeration was quite similar, with 45.6\% (n, 963) preferring shopping malls, 46.6\% URSCs and 7.8\% indifferent. In the case of Ljubljana, the preference clearly shifts towards shopping malls, with more than two thirds of respondents $(68.5 \%$;, 691) favouring this created agglomeration format (URSCs 24.3\%; neutral 7.2\%). The results from Bratislava are even more explicit in terms of the dominance of malls. Here, almost four out of five respondents preferred shopping malls $(78.7 \% ; \mathrm{n}, 514)$ over URSCs $(16.3 \%)$. Only $5 \%$ expressed no preference for either format. These results give a first indication of an uneven competition between a comparably large number of new and professionally managed shopping malls, and a limited number of barely managed or marketed URSCs.

The preference towards specific URSCs and shopping malls in terms of the highest number of visits, shows a clear picture of preferences for a few agglomerations (see Table 1 and Table 2). Figures 2, 3 and 4 offer visual representations of where the preferred retail centres are in Vienna, Ljubljana and Bratislava respectively. 
Table 1: Patronised retail agglomerations

\begin{tabular}{|c|c|c|c|c|}
\hline Case & $\begin{array}{l}\text { Inner city retail and service } \\
\text { clusters }\end{array}$ & $\%$ & Shopping malls & $\%$ \\
\hline Vienna & $\begin{array}{l}\text { Mariahilferstraße } \\
\text { Kärntnerstraße }\end{array}$ & $\begin{array}{r}52.8 \\
14.5 \\
(\mathrm{n}, 851) \\
\end{array}$ & $\begin{array}{l}\text { Shopping City Süd } \\
\text { Donauzentrum }\end{array}$ & $\begin{array}{c}26.8 \\
14.8 \\
(\mathrm{n}, 915) \\
\end{array}$ \\
\hline Ljubljana & $\begin{array}{l}\text { Čopova ulica } \\
\text { Slovenska cesta }\end{array}$ & $\begin{array}{r}57.6 \\
10.0 \\
(\mathrm{n}, 684) \\
\end{array}$ & $\begin{array}{l}\text { City Park Ljubljana } \\
\text { BTC City }\end{array}$ & $\begin{array}{c}39.5 \\
25.3 \\
(n, 691)\end{array}$ \\
\hline Bratislava & $\begin{array}{l}\text { City centre II (Obchodná ulica, } \\
\text { Poštová ulica, Námestie SNP) } \\
\text { City centre I (Laurinská ulica, } \\
\text { Michalská ulica, Pánska ulica) }\end{array}$ & $\begin{array}{r}71.8 \\
14.4 \\
(\mathrm{n}, 195)\end{array}$ & $\begin{array}{l}\text { Avion Shopping Park } \\
\text { Aupark Bratislava } \\
\text { Shopping Centre }\end{array}$ & $\begin{array}{c}27.3 \\
27.5 \\
(n, 458)\end{array}$ \\
\hline
\end{tabular}

Table 2: Characterisation of key case study agglomerations

\begin{tabular}{|c|c|c|c|}
\hline City & Centre & $\begin{array}{l}\text { Gross lease area } \\
\left(\mathrm{m}^{2}\right) \text { for mall space }\end{array}$ & Rent $\left(E U R / m^{2} /\right.$ month $)$ \\
\hline Vienna & $\begin{array}{l}\text { Mariahilferstraße } \\
\text { Kärntnerstraße } \\
\text { Shopping City Süd } \\
\text { Donauzentrum }\end{array}$ & $\begin{array}{l}178.300 \\
- \\
124,000 \\
98,000\end{array}$ & $\begin{array}{l}60-200 \\
170-350 \\
\text { Shopping centres, } 40-80\end{array}$ \\
\hline Ljubljana & $\begin{array}{l}\text { Čopova ulica } \\
\text { Slovenska cesta } \\
\text { City Park Ljubljana } \\
\text { BTC City }\end{array}$ & $\begin{array}{l}- \\
- \\
53,500 \\
96,900\end{array}$ & $\begin{array}{l}\text { Similar across formats: } \\
\text { Smaller shops }\left(<100 \mathrm{~m}^{2}\right): 50 \\
\text { Medium size shops }\left(100-350 \mathrm{~m}^{2}\right) \text { : } \\
20-40 \\
\text { Larger shops }\left(>350 \mathrm{~m}^{2}\right): 15-30\end{array}$ \\
\hline Bratislava & $\begin{array}{l}\text { City centre II } \\
\text { (Obchodná ulica, } \\
\text { Poštová ulica, } \\
\text { Námestie SNP) } \\
\text { City centre I } \\
\text { (Laurinská ulica, } \\
\text { Michalská ulica, } \\
\text { Pánska ulica) } \\
\text { Avion Shopping } \\
\text { Park } \\
\text { Aupark }\end{array}$ & $\begin{array}{l}65,000 \\
42,000\end{array}$ & Prime shopping centre: 23.5 \\
\hline
\end{tabular}

Source: Colliers International (2013; 2014a; 2014b) 
Figure 2: Preferred Agglomerations in Vienna

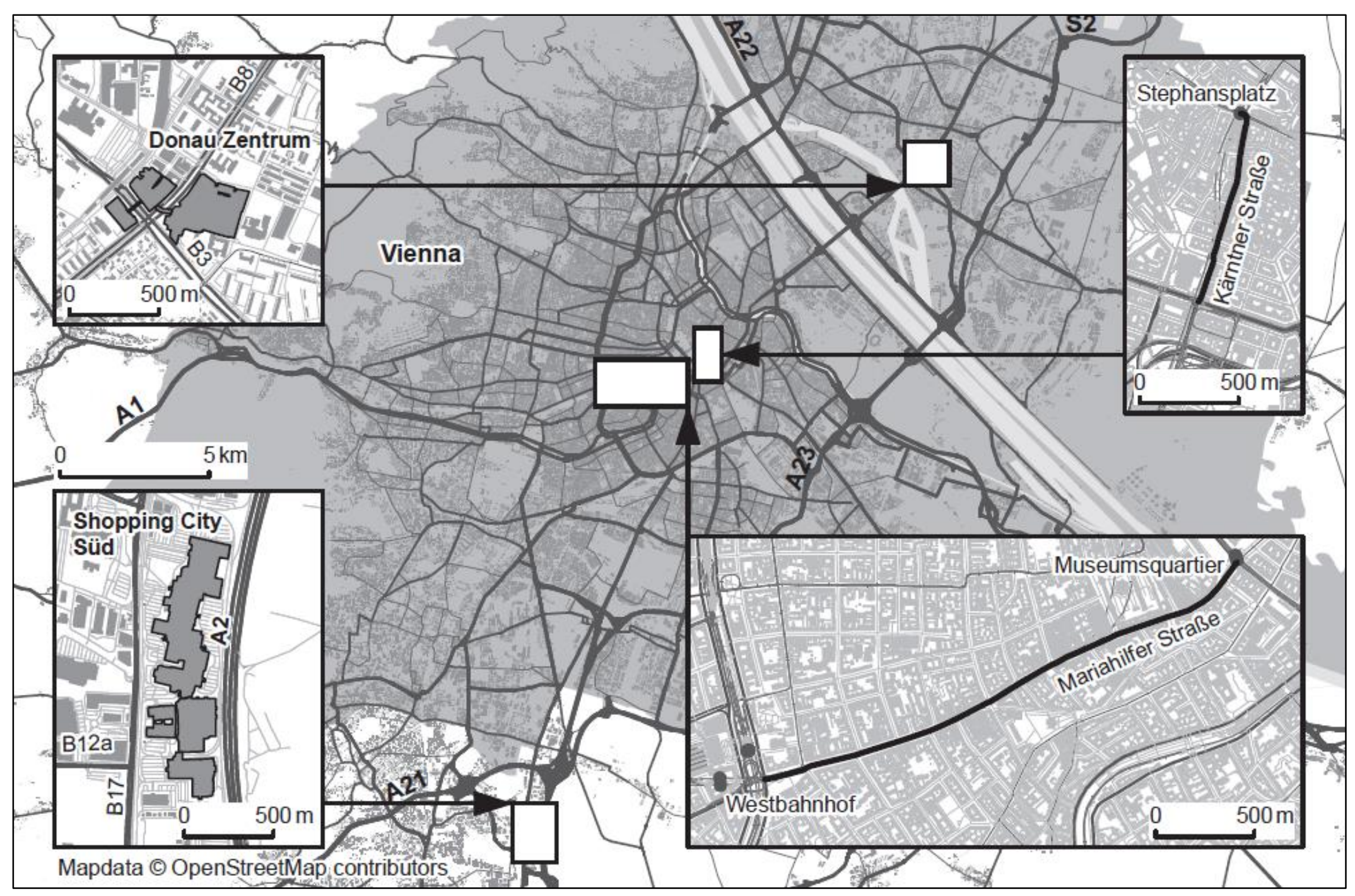


Figure 3: Preferred Agglomerations in Ljubljana

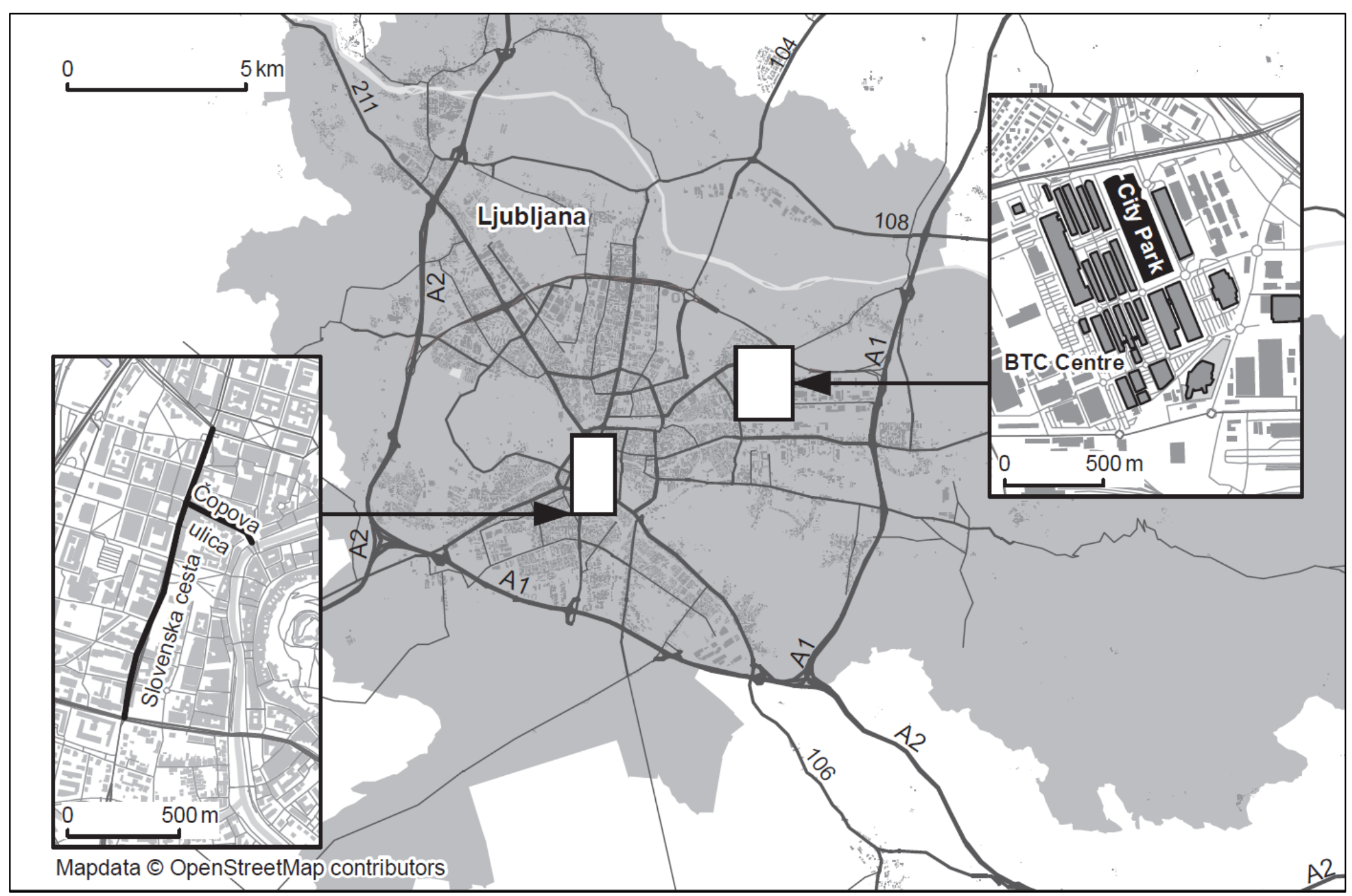


Figure 4: Preferred Agglomerations in Bratislava

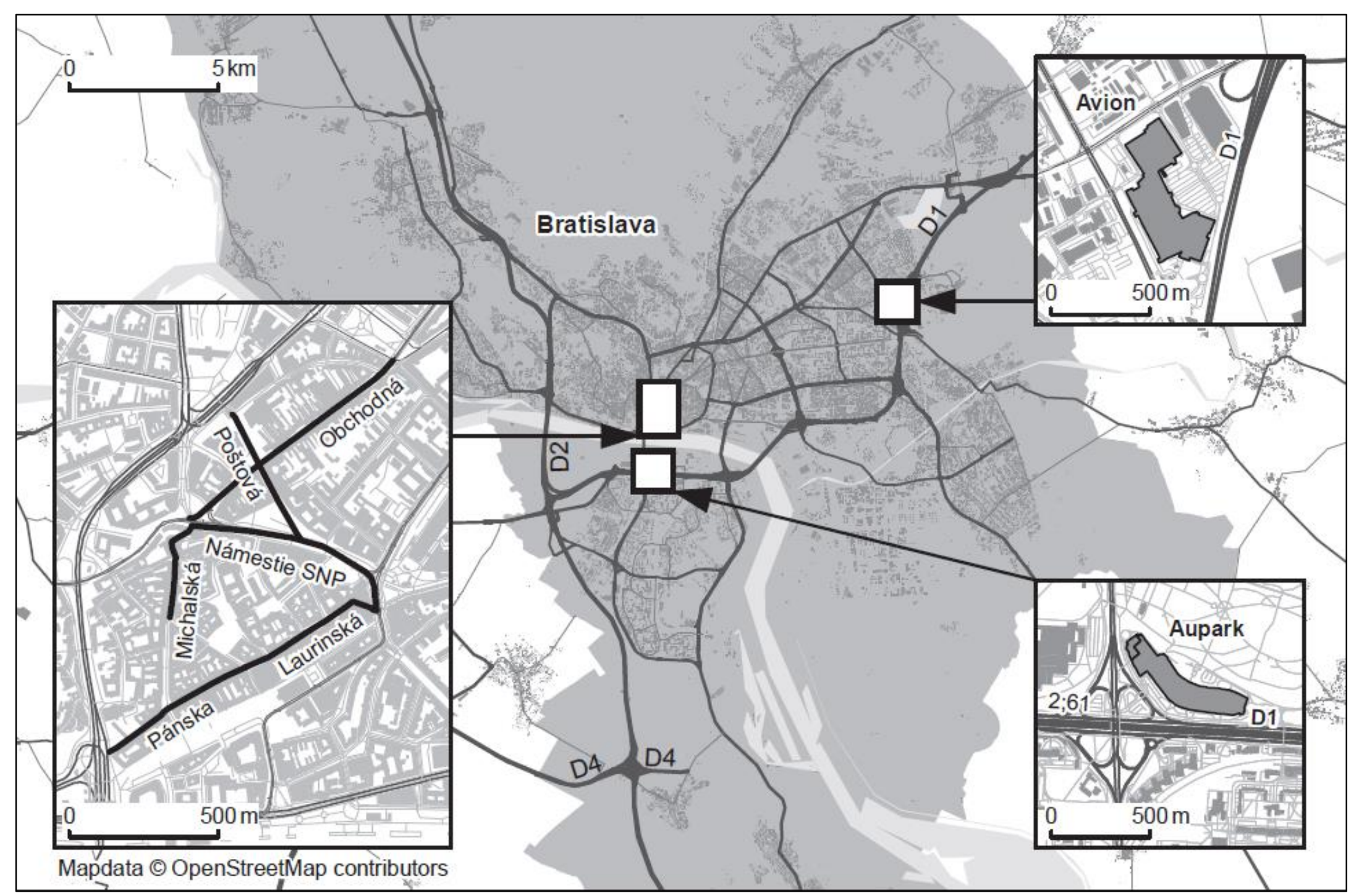


In terms of Vienna two first-order high streets are most popular with our respondents (see Figure 2; Table 1 and 2). Both account for highly successful retail locations unlike most other second-order high streets with more regional catchments within the city. The Mariahilferstraße is partly pedestrianized while the Kärntnerstraße is fully pedestrianized, making access for motorists challenging. Nevertheless, both locations can be accessed easily by the means of public transport (i.e. tram, subway and bus). They can be regarded as being very successful in attracting both customers and tenants. In particular, the appealing architecture in these streets contribute to a unique shopping experience for customers compared to enclosed malls.

The two preferred shopping malls account for the oldest, largest and arguably most successful in the Vienna greater area. The Shopping City Süd is one of the biggest across Europe in terms of tenants, located to the south of the city and is very well connected to a string of highways. The Donauzentrum appeals to a comparably regional clientele given its location across the Danube in the north of the city and is deeply embedded in the urban area. Its access via public transport is better in comparison to the Shopping City Süd. The competition between the two high streets and two malls is much more balanced compared to the other two city cases.

The two preferred high streets in Ljubljana are significantly smaller in size compared to those in Vienna (see Figure 3). These two retail clusters (Čopova ulica and Slovenska cesta) are second-order high streets that represent the main urban shopping facilities apart from malls. As in Vienna, the main asset of these shopping destinations is the embeddedness in the urban environment, their central location within the urban catchment of Ljubljana as well as the proximity of inner-city shopping centres.

The most frequently patronised mall in Ljubljana is City Park which is itself located within the second most frequently patronised shopping destination, BTC City. From Figure 3 it can be seen that BTC City has the character of a retail park with large stand-alone retail stores 
and parades. Both shopping centres together account for one of the largest retail agglomerations across the country and feature a large variety of national and international tenants. In particular, for the car-borne customer this retail location benefits from ease of access. The competition between the two categories of agglomeration format is rather uneven in favour of the shopping centres. In particular, the size, the number as well as the size of tenants, along with the accessibility of the centre, underpin its popularity.

The relationship between - and the general characterisation of - preferred URSCs and malls is similar in Bratislava. A set of six short streets and squares in the heart of the historic part of the city (Obchodná ulica, Poštová ulica, Námestie SNP, Laurinská ulica, Michalská ulica, Pánska ulica) represent the most important destination for shoppers outside malls. Typically local and regional retailers operate stores there, providing - together with the appealing architecture of the city centre - a distinctive and differentiated shopping experience for customers. The stores are embedded in a network of restaurants, bars and coffee shops which further support patronage and serve to increase dwell time. Nevertheless, the accessibility by car is less convenient compared to shopping malls.

The two preferred Bratislava malls (Avion Shopping Park and the Aupark Bratislava Shopping Centre) represent the most powerful players in the region (Figure 4). Compared to the malls in the other two cities, these two malls are newer and combine contemporary mall design and functionality. Both are of significant size containing stores of national and international retail chains and are well connected to the road network. For more details on the two shopping malls see Križan et al. (2014). The competition between the inner-city retail cluster and the two malls is very uneven in favour of the latter. Due to the growing attractiveness and number of shopping malls, the importance of the city centre as a retail location has gradually decreased. 
To summarise, in all cases - except for shopping malls in Bratislava - respondents most frequently patronise one particular agglomeration over all the others (see percentages in Table 1). In Bratislava, two shopping malls appear to be equally popular. The preferences in each format type again show that most respondents patronise URSCs less often than malls particularly so in the Bratislava case. All of the most frequently patronised malls are in semiperipheral and peripheral locations outside of the city centres, whereas all URSCs are embedded very close to or in the city centres and face the associated challenges of vehicular accessibility. All shopping malls are significantly larger in terms of number of tenants and normally include attractive entertainment and hospitality features. All are managed and marketed centrally. There is no powerful agglomeration management or marketing in place in any of the three sets of URSCs, but attempts at collaborative marketing efforts, such as Christmas lights and cooperative promotions/advertising, are visible.

To test our conceptual model we exclusively compare the most frequently patronised agglomerations of each format in each city (see Table 1). This focus is driven by the fact that we mostly see a clear preference towards particular malls or URSCs. The results of our model estimation are as follows.

\section{Antecedents of patronage intentions $\left(H_{m l}\right)$}

Vienna: The tenant mix plays a significant, and the most substantial, role in making two of the Viennese agglomerations more frequently patronised compared to others $\left(\gamma_{113}, .571, \mathrm{p}<.001\right.$; $\left.\boldsymbol{y}_{223}, .357, \mathrm{p}<.001\right)$. Another significant impact factor on patronage intentions is accessibility, although the effect sizes are lower in total, and higher for the URSCs $\left(\gamma_{111}, .191, \mathrm{p}<.001 ; \gamma_{221}\right.$, $.109, \mathrm{p}<.05)$. The results reveal another similarity, which is that parking seems to have no significant impact in either agglomeration type $\left(\gamma_{112},-.018, \mathrm{p}>.05 ; \gamma_{222}, .069, \mathrm{p}>.05\right)$. Although effect sizes for atmosphere are comparable in both agglomerations, the marginal effect is only significant in the URSC setting $\left(\gamma_{114}, .138, \mathrm{p}<.001 ; \gamma_{224}, .096, \mathrm{p}>.05\right)$. 
Based on these results we tested $\mathrm{H}_{\mathrm{m} 1}$ and applied a multi-group comparison between each structural effect across the two agglomeration formats. The $\chi^{2}$ difference test revealed only one significant difference in terms of the effects of the tenant mix on patronage intentions $\left(\Delta \chi^{2}, 14.13 ; d f, 1 ; \mathrm{p}<.001\right)$. Thus, the agglomeration format only moderates this effect and thus we only confirm $\mathrm{H}_{\mathrm{m} 1}$ here. The $\chi^{2}$ difference is lower than $3.82(d f, 1)$ and thus insignificant for all other effects in our model leading to a rejection of $\mathrm{H}_{\mathrm{m} 1}$ there.

Ljubljana: For the most frequently patronised agglomerations in Ljubljana, tenant mix again impacts upon patronage intentions most significantly and substantially $\left(\boldsymbol{\gamma}_{113}, .376\right.$, $\left.\mathrm{p}<.001 ; \gamma_{223}, .316, \mathrm{p}<.001\right)$. The atmosphere also affects the patronage variable significantly but less strongly $\left(\gamma_{114}, .199, \mathrm{p}<.001 ; \gamma_{224}, .207, \mathrm{p}<.001\right)$. The parking coefficient is not significant and, for both agglomerations, marginal $\left(\gamma_{112},-.090, \mathrm{p}>.05 ; \gamma_{222},-.021, \mathrm{p}>.05\right)$. Accessibility has a significant and medium-sized effect, in the URSC model exclusively ( $\gamma_{111}$, $\left..257, \mathrm{p}<.001 ; \gamma_{221}, .085, \mathrm{p}>.05\right)$

The subsequent $\chi^{2}$ difference test between the structural effects only show variance between the effect of accessibility and patronage intention across the two agglomeration formats. $\mathrm{H}_{\mathrm{m} 1}$ can be confirmed for this effect $\left(\Delta \chi^{2}, 5.570 ; d f, 1 ; \mathrm{p}<.01\right)$ and rejected for the others in the model $\left(\Delta \chi^{2}<3.82 ; d f, 1 ; \mathrm{p}>.05\right)$.

Bratislava: Atmosphere $\left(\gamma_{114}, .367, \mathrm{p}<.001 ; \gamma_{224}, .285, \mathrm{p}<.001\right)$, tenant mix $\left(\gamma_{113}, .331\right.$, $\left.\mathrm{p}<.01 ; \gamma_{223}, .262, \mathrm{p}<.001\right)$ and parking $\left(\gamma_{112}, .155, \mathrm{p}<.05 ; \gamma_{222}, .234, \mathrm{p}<.001\right)$ drive the patronage intentions towards Bratislava's preferred agglomerations, with the effects most substantial for the first two attributes. Accessibility however affects the patronage variable for the URSC but not the shopping mall $\left(\gamma_{111}, .201, \mathrm{p}<.01 ; \gamma_{221}, .054, \mathrm{p}>.05\right)$. 
Testing of the first hypotheses reveals that the $\chi^{2}$ differences between the structural effects reveal no significant difference $\left(\Delta \chi^{2}<3.82 ; d f, 1 ; p>.05\right)$. Thus $\mathrm{H}_{\mathrm{m} 1}$ has to be rejected as the agglomeration format does not moderate any effects in the model.

\section{Differences across urban areas $\left(H_{m 2 a, b}\right)$}

In terms of URSCs we see no differences in terms of the impact of accessibility between the three cities $\left(\Delta \chi^{2}<3.82 ; d f, 1 ; p>.05\right)$. In terms the tenant mix, the impact is different across all three cities $\left(\Delta \chi^{2}>3.82 ; d f, 1 ; p<.05\right)$. The impact of parking is different between Ljubljana and Bratislava $\left(\Delta \chi^{2}, 7.901 ; d f, 1 ; p<.01\right)$ and of atmosphere between Vienna and Bratislava $\left(\Delta \chi^{2}\right.$, 17.084; $d f, 1 ; p<.05) . \mathrm{H}_{m 2 \mathrm{a}}$ can thus only be confirmed for the tenant mix and selectively between cities of parking and atmosphere.

When looking at shopping malls the number of differences are even less. Here we see no difference in terms of accessibility and tenant mix $\left(\Delta \chi^{2}<3.82 ; d f, 1 ; p>.05\right)$. The impact of parking is different between Ljubljana and Bratislava $\left(\Delta \chi^{2}, 9.23 ; d f, 1 ; p<.01\right)$ and of atmosphere between Vienna and Bratislava $\left(\Delta \chi^{2}, 5.34 ; d f, 1 ; p<.05\right) . \mathrm{H}_{m 2 \mathrm{~b}}$ cannot be confirmed for any of the impact of attributes for all cities nor selectively for parking and atmosphere.

\section{Relationship between patronage intentions towards URSC and malls}

To test our final hypothesis $\mathrm{H}_{3}$ we had to reduce our sample to those respondents who patronise both agglomeration formats. In all three city cases the co-variances between patronage intentions towards both agglomerations is positive ( $\Phi_{12}$ : Vienna, .292; $p<.001$; Ljubljana, .160; $p<.001$; Bratislava, .325; $p<.001)$. When applying $\chi^{2}$ difference tests we cannot reveal any significant differences between the three cases $\left(\Delta \chi^{2}<3.82 ; d f, 1 ; p>.05\right)$. As the co-variance shows a significant yet positive sign we consequently reject our third hypothesis and conclude that patronage intention to one format has a positive effect on the other and vice versa. 
Table 3. Structural effects

\begin{tabular}{|c|c|c|c|c|c|c|c|c|c|c|c|}
\hline \multirow{2}{*}{$\begin{array}{l}\text { City } \\
\text { Formats }\end{array}$} & \multicolumn{2}{|c|}{ Vienna } & \multirow[b]{2}{*}{$\Delta$} & \multicolumn{2}{|c|}{ Ljubljana } & \multicolumn{3}{|c|}{ Bratislava } & \multicolumn{3}{|c|}{$\Delta$ Urban Areas } \\
\hline & URSC & SHMAL & & URSC & SHMAL & $\Delta$ & URSC & SHMAL & $\Delta$ & $\Delta$ URSC & $\triangle$ SHMAL \\
\hline Accessibility $\rightarrow$ PI $\left(\gamma_{111}, \gamma_{211}\right)$ & $.191^{* * *}$ & $.109^{*}$ & - & $.257^{* * *}$ & $.085^{\mathrm{ns}}$ & $*$ & $.201^{* *}$ & $.054^{\mathrm{ns}}$ & - & $\mathrm{A}^{\mathrm{ns}}, \mathrm{B}^{\mathrm{ns}}, \mathrm{C}^{\mathrm{ns}}$ & $\mathrm{A}^{\mathrm{ns}}, \mathrm{B}^{\mathrm{ns}}, \mathrm{C}^{\mathrm{ns}}$ \\
\hline Parking $\rightarrow$ PI $\left(\gamma_{112}, \gamma_{222}\right)$ & $-.018^{\mathrm{ns}}$ & $.069^{\mathrm{ns}}$ & - & $-.090^{\mathrm{ns}}$ & $-.021^{\mathrm{ns}}$ & - & $.155^{*}$ & $.234^{* * * *}$ & - & $\mathrm{A}^{\mathrm{ns}}, \mathrm{B}^{\mathrm{ns}}, \mathrm{C}^{*}$ & $\mathrm{~A}^{\mathrm{ns}}, \mathrm{B}^{\mathrm{ns}}, \mathrm{C}^{* *}$ \\
\hline Tenant mix $\rightarrow$ PI $\left(\boldsymbol{\gamma}_{\mathbf{1 1 3}}, \boldsymbol{\gamma}_{\mathbf{2 2 3}}\right)$ & $.571^{* * *}$ & $.357^{* * *}$ & $* * *$ & $.376^{* * *}$ & $.316^{* * *}$ & - & $.313^{* *}$ & $.262^{* * * *}$ & - & $\mathrm{A}^{* * *}, \mathrm{~B}^{* *}, \mathrm{C}^{*}$ & $\mathrm{~A}^{\mathrm{ns}}, \mathrm{B}^{\mathrm{ns}}, \mathrm{C}^{\mathrm{ns}}$ \\
\hline Atmosphere $\rightarrow$ PI $\left(\gamma_{114}, \gamma_{224}\right)$ & $.138^{* * *}$ & $.096^{\mathrm{ns}}$ & - & $.199^{* * *}$ & $.207^{* * *}$ & - & $.367^{* * *}$ & $.285^{* * *}$ & - & $\mathrm{A}^{*}, \mathrm{~B}^{\mathrm{ns}}, \mathrm{C}^{\mathrm{ns}}$ & $\mathrm{A}^{\mathrm{ns}}, \mathrm{B}^{*}, \mathrm{C}^{\mathrm{ns}}$ \\
\hline$r_{\eta 1}^{2}$ & .510 & .196 & & .363 & .225 & & .434 & .658 & & & \\
\hline CFI; TLI & \multicolumn{2}{|c|}{$.966 / .955$} & \multicolumn{3}{|c|}{$.958 / .945$} & \multicolumn{3}{|c|}{$.951 / .935$} & & & \\
\hline $\mathrm{RMSEA} ; \chi^{2} / \mathrm{df}$ & \multicolumn{2}{|c|}{$.046 / 2.015$} & \multicolumn{3}{|c|}{$.049 / 2.212$} & \multicolumn{3}{|c|}{$.057 / 2.235$} & & & \\
\hline City & \multicolumn{2}{|c|}{ Vienna (n, 219) } & \multicolumn{3}{|c|}{ Ljubljana (n, 308) } & \multicolumn{3}{|c|}{ Bratislava $(\mathrm{n}, 97)$} & & \multirow{2}{*}{\multicolumn{2}{|c|}{$\Delta$ Urban Areas }} \\
\hline Formats & \multicolumn{2}{|c|}{ URSC and SHMAL } & \multicolumn{3}{|c|}{ URSC and SHMAL } & \multicolumn{3}{|c|}{ URSC and SHMAL } & & & \\
\hline $\mathrm{PI}_{\text {URSC }} \leftarrow \rightarrow \mathrm{PI}_{\text {SHMAL }}\left(\Phi_{12}\right)$ & \multicolumn{2}{|c|}{$.292^{* * * *}$} & \multicolumn{3}{|c|}{$.160^{* * *}$} & \multicolumn{3}{|c|}{$.325^{* * *}$} & & \multicolumn{2}{|c|}{$\mathrm{A}^{\mathrm{ns}}, \mathrm{B}^{\mathrm{ns}}, \mathrm{C}^{\mathrm{ns}}$} \\
\hline CFI; TLI & \multicolumn{2}{|c|}{$.994 / .978$} & \multicolumn{3}{|c|}{$.991 / .982$} & \multicolumn{3}{|c|}{$.970 / .932$} & & & \\
\hline
\end{tabular}

Caption: URSC, most preferred urban retail and service clusters; SHMAL, most preferred shopping malls; $\gamma$, gamma, effects between exogenous factors ( $\left.\xi_{1}-\xi_{4}\right)$ and endogenous factor $\left(\eta_{1}\right){ }^{*}$, significance level $p<.05 ;{ }^{* *}$, significance level $p<.01 ;{ }^{* * *}$, significance level $p<.001$; ns, significance level $p>.1$; PI, patronage intentions; A, difference between the sample of Vienna and Ljubljana; B, difference between the sample of Vienna and Bratislava; C, difference between the sample of Ljubljana and Bratislava; Cut-off values for global fit measures: Absolute fit measure: RMSEA (Root Mean Square Error of Approximation)<.08; incremental fit measures: CFI(Comparative Fit Index $) /$ TLI(Tucker-Lewis Index $)>.9 />.9$; parsimony fit measures: Normed $\chi^{2}(\mathrm{CMIN} / d f)<3$; 


\section{Findings and discussion}

Different characteristics of formats yet similar drivers of competitiveness: The first key finding of this research is the unexpected absence of differences between the impacts of key agglomeration attributes or network resources on patronage across different formats. This leads to the conclusion that agglomerations of different formats are essentially store networks and thus that the drivers of why consumers shop at them are - apart from very few exceptions - remarkably similar. Consistent with the findings of, for example, Teller and Reutterer (2008) the major driver is the tenant mix.

Another key finding is that when comparing the agglomeration formats between different areas we find more homogeneous results in the context of shopping malls as compared to URSCs. This implies a uniqueness of evolved retail agglomerations in the eyes of the consumers - for both good and ill - compared with the standardisation of shopping mall management and marketing concepts across created retail and service agglomeration contexts. In particular tenant mix represents a source of uniqueness of URSCs in contrast to the shopping malls. We thus conclude that in particular for the evolved agglomeration formats the tenant mix reveals to be a source of competitiveness as it is a distinctive feature and has the highest potential to increase patronage.

Competitors or complements? One of the most striking findings from the data analysis was that both created and evolved agglomeration formats were not necessarily in fierce competition such that increases in patronage for one was associated with decreases in patronage of the other. Instead, we found the opposite - an apparent virtuous and complementary relationship whereby patronage of malls was associated with patronage of URSCs such as city/town centres and high streets. This phenomenon becomes more understandable when looking at the main activities of respondents when patronising their preferred agglomeration. Table 4 shows that malls being 
significantly more used as places to shop for products whereas the evolved centres are used more for other reasons, such as dining and dwelling.

Table 4: Reasons for patronising different agglomeration formats

\begin{tabular}{lccccccccc}
\hline \multirow{2}{*}{$\begin{array}{l}\text { City } \\
\text { Centres }\end{array}$} & \multicolumn{3}{c}{ Vienna } & \multicolumn{3}{c}{ Ljubljana } & \multicolumn{3}{c}{ Bratislava } \\
\cline { 2 - 9 } & URSC & SHMAL & $\Delta$ & URSC & SHMAL & $\Delta$ & URSC & SHMAL & 4 \\
\hline Buy products $^{1}$ & 77.8 & 87.1 & $\chi^{2}, 18.93 ;$ & 57.0 & 89.0 & $\chi^{2}, 126.5$ & 48.7 & 76.0 & $\chi^{2}, 42.49 ;$ \\
Buy services $^{2}$ & 4.4 & 4.5 & $d f, 2 ;$ & 9.8 & 3.6 & $6 ; d f, 2 ;$ & 17.3 & 10 & $d f, 2 ;$ \\
Other activities $^{3}$ & 17.8 & 8.4 & $\mathrm{p}<.001$ & 33.2 & 7.4 & $\mathrm{p}<.001$ & 34.0 & 14.0 & $\mathrm{p}<.001$ \\
\hline Caption: 1, products for him/herself, someone else and for work; 2, entertainment, hospitality and other services; 3, spending \\
time, meeting/accompanying someone, informing him/herself; 4 , difference between agglomeration formats $\left(\chi^{2}\right.$-test);
\end{tabular}

This contrasts with the findings of much of the research literature that has charted the rise of malls and the subsequent decline of traditional, evolved spaces of consumption (Hughes and Jackson, 2015). The obvious question is whether we can explain the complementary patronage relationship between the two types of centre. We suggest two related explanatory factors:

The Darwinian evolution of urban places has led to a situation where both malls and URSCs have developed such that they provide a retail, service and experiential offer that is in a complementary state such that they can successfully co-exist. In essence, by offering a differentiated retail and service offer to malls, evolved URSCs have also succeeded. Importantly, this does not disprove the wide array of research evidence that points to the negative impact of out of town malls on evolved (town and city) centres (e.g., Thomas and Bromley, 1993); indeed, it is highly likely that traditional centres that could not adapt to provide a complementary offer will have ceased to exist in their own right and are therefore de facto not in our sample. The interpretation of the findings of our multiple case studies lead us to the assumption that the evolved centres we appraised appeared to survive because they were not simply providing a retail offer directly and holistically substitutable by the mall - but more so, they also provide a broader leisure proposition with tourist destinations, services such as 
restaurants, bars and coffee shops, and are the location of high worker populations which ensure high levels of footfall (see Table 4). Second, related to the above arguments, the ability for a centre to evolve and withstand exogenous shocks such as competition in the form of out of centre malls, has theoretical foundation within recent social science literature. Scholarship within urban and regional studies as well as economic geography has adopted theories of resilience from scientific traditions to help explain enduring degrees of success of some established centres.

Balsas (2014) defines resilience as the capacity of a network to withstand change, shock or continued modifications to continue their development patterns in similar or reinvigorated ways. Importantly, there is no universally agreed definition of resilience but it is notable that Simmie and Martin (2010) reject 'equilibrist approaches' which suggest centres and wider regions (and the firms, organisations and institutions that make them up) always return to their previous states - instead contending that they are constantly changing and adapting. Similarly, Dobson (2015) notes resilience is not simply a process by which an agglomeration might return to its earlier equilibrium state following exogenous shock - instead, this process of 'transition' emphasises the possibility of moving to a 'changed state' which is suited to the new reality. Martin (2011) raises the concept of 'adaptive resilience' to describe how places are complex adaptive systems - in our case, retail and service agglomerations - which can self-organise and evolve through dynamic processes to reorganise and thus mitigate the effects of exogenous shocks.

For some commentators, resilience of a centre is solely 'the consequence of retailers' strategies' (Erkip et al., 2014, p 113). However, more commonly, it is recognised that centres are a strategic networked ecosystem that evolves through public, semi-public and private actors which might be partly the product of retailers' strategies for example, but equally might be public-private partnerships in urban place management (Van den Berg and Braun, 1999). In 
addition, a variegated picture of the role of retailers in sustaining resilience emerges from the literature. The concept of adaptive resilience was subsequently picked up by Wrigley and Dolega (2011) in their analysis of evolved centres in the UK which supported a view that there was a degree of protection for a centre from diversity in terms of the mix of retail and services as well as variation in retail ownership between large ('corporate') as well as smaller, independent stores (see also Wahlberg, 2016).

We therefore propose that the URSCs that we have surveyed in this research, are shown to have exhibited some degree of adaptive resilience by providing a differentiated offer and characteristics compared to out of centre malls that might otherwise have out-competed them solely on a 'corporate' and/or 'standardised' retail offer. We posit that URSCs have adapted and evolved to provide something different which has served to retain their position in the eyes and behaviour of consumers.

\section{Practical implications}

Beyond the specificities of the three cities, there are a range of implications for retail marketing as well as for the practical management of retail centres. This paper has emphasised the network character of agglomerations, and the competitive relationship between different formats; in particular URSCs and shopping malls. In this international study, consumers' perceptions were used to identify resources and capabilities of store networks that might serve as drivers of competitiveness. Importantly, the findings do not suggest that the competition between agglomeration formats is a bad thing or that URSCs will suffer and shopping malls succeed. On the contrary, the results show that URSCs possess resources that can be utilised to increase their competitiveness. Victor Gruen saw the pressure and dominance of shopping malls in urban markets as a positive development, constantly pushing retail and service organisations with stores in urban areas to modernise and reinvent URSCs in order to survive (Hardwick, 2004). The results of this study can help them to do exactly that. 
By identifying those attributes that customers perceived as influencing their patronage intentions the most, we have revealed those resources and capabilities of store networks that could serve as the drivers of competitiveness, and could consequently be developed into competitive advantages. The tenant mix and thus the 'cumulative attraction' of stores stands out among the four drivers investigated. This finding leads to the conclusion that network theory is useful for understanding the phenomenon of retail agglomerations, since the interdependencies between the nodes (stores) is of superior importance for patronage and thus competitiveness. Importantly for practice, such findings support recent research from both developed and developing markets which suggests that resilience of traditional unplanned central shopping locales and streets stems from consumer diversity, retailer variety and quality, as well as some degree of complementary between the retail offers (Ozuduru et al., 2014; Wrigley and Dolega, 2011). This involves developing an insightful understanding of what customers want, how they undertake shopping and therefore the linkages between retailers and types of services that emerges (Cachinho, 2014).

Finally, it can be concluded that the findings clearly show the disadvantages of URSCs (representing emergent networks) compared to shopping malls (representing strategic or value nets), in terms of leveraging the identified sources of competitiveness (Möller and Rajala, 2007). Given the clear structures, roles and goals of tenants based on lease agreements, the management of shopping malls could better react to such results by, for example, adapting the width and depth of the store mix, changing atmospheric stimuli, or any other infrastructural services. In contrast, the challenge for URSCs is to manage intra-firm (internal) and inter-firm (external) activities and resources. URSC management is dependent on convincing tenants to build alliances, cooperate in, for example, marketing campaigns, and combine their resources as a response to the increasingly competitive environment (Chetty and Wilson, 2003). Despite the demands involved, these results provide a pathway to achieving success in highly 
competitive markets, though we acknowledge the challenges involved in successfully encouraging a wide array of disparate stakeholders within an agglomeration to work cohesively together for the common good. Nevertheless, there are strong reasons for tenants of agglomerations to form collaborations within the networks in order to create advantages and resilience - in terms of risk, resource sharing or learning from others in order to outperform competing agglomeration formats, in particular shopping malls (Chetty and Michailova, 2011; Teller et al., 2016).

\section{Limitations}

As with all research studies, there are some limitations to this research. First is its focus on the dominant retail agglomeration formats, URSCs and shopping malls, in European capital cities. The results depend on retail markets in the main European cities still having significant inner city retail and service clusters capable of acting as alternatives to shopping centres for consumers. Thus, replication studies in, say, North America or in smaller urban settings are necessary. Further, the focus here was on the most frequently visited agglomerations, and neglected agglomerations of second choice.

In our analyses we did not take into consideration differences between customer groups. Further research could look into the association between core attributes and patronage intentions by testing the effects of moderating variables, e.g. in terms of demo- and psychographics, and mediating variables such as satisfaction with the agglomeration, positive word of mouth or agglomeration attractiveness.

Another limitation of the survey approach applied here is clearly the coverage error towards younger cohorts. Respondents of retirement age are underrepresented in all three studies. Thus, future research could look explicitly at elderly patrons of retail agglomerations, and investigate potential deviations from the results presented in this paper. 
The low coefficients of determination show that other factors may potentially affect patronage intentions. Factors frequently used in comparable studies, such as manoeuvrability or infrastructural services, could be added to the model.

Finally, we do appreciate that our measure of competitiveness is focused on the consumer dimension and neglects objective measures such as sales, footfall, conversion rates or profits as such secondary data are rarely available for evolved agglomerations. Nevertheless, future research could include such hard business measures and investigate their relationship with perceptional and intentional measures as used in our model. 


\section{References}

Alexander, A., Teller, C., \& Roggeveen, A.L. (2016). The boundary spanning of managers within service networks. Journal of Business Research, in print. DOI: http://dx.doi.org/10.1016/j.jbusres.2016.05.018.

Anderson, J.C., \& Gerbing, D.W. (1988). Structural equation modeling in practice: A review and recommended two-step approach. Psychological Bulletin, 103, 411-423. DOI: 10.1037/0033-2909.103.3.411.

Arentze, T.A., Oppewal, H., \& Timmermans, H.J.P. (2005). A multipurpose shopping trip model to assess retail agglomeration effects. Journal of Marketing Research, 42, 109115. DOI: $10.1509 / j m k r .42 .1 .109 .56884$.

Bagozzi, R.P., \& Baumgartner, H. (1994). The evaluation of structural equation models and hypothesis testing. In R. P. Bagozzi (Ed.), Principles of Marketing Research (pp. 386422). Cambridge: Blackwell.

Bagozzi, R.P., \& Yi, Y. (1988). On the evaluation of structural equation models. Journal of the Academy of Marketing Science, 16, 74-94. DOI: 10.1177/009207038801600107.

Balsas, C.J.L. (2014). Downtown resilience: A review of recent (re)developments in Tempe, Arizona. Cities, 36, 158-169. DOI: 10.1016/j.cities.2012.10.002.

Behling, O., \& Law, K.S. (2000). Translating questionnaires and other research instruments: Problems and solutions. Thousand Oaks, CA: Sage.

Berry, B.J., \& Kasarda, J.D. (1977). Contemporary urban ecology. London: Macmillan.

Bloch, P.H., Ridgway, N.M., \& Dawson, S.A. (1994). The shopping mall as consumer habitat. Journal of Retailing, 70, 23-42. DOI: 10.1016/0022-4359(94)90026-4.

Brown, T.A. (2006). Confirmatory factor analysis for applied research. New York, NY: Guildford Press.

Cachinho, H. (2014). Consumerscapes and the resilience assessment of urban retail systems. Cities, 36, 131-144. DOI: 10.1016/j.cities.2012.10.005.

Chetty, S.K., \& Michailova, S. (2011). Geographical proximity and inter-firm collaboration. Journal of General Management, 36, 71-87. DOI: 10.1111/j.1468-2370.2006.00121.x.

Chetty, S.K., \& Wilson, H.I.M. (2003). Collaborating with competitors to acquire resources. International Business Review, 12, 61-81. DOI: 10.1016/S0969-5931(02)00088-4. 
Churchill, G.A. (1979). A paradigm for developing better measures of marketing constructs. Journal of Marketing Research, 16, 64-73. DOI: 10.2307/3150876.

Coca-Stefaniak, J.A., Parker, C., Quin, S., Rinaldi, R., \& Byrom, J. (2009). Town centre management models: A european perspective. Cities, 26, 74-80. DOI: 10.1016/j.cities.2008.12.001.

Crawford, M. (1992). The world in a shopping mall. In M. Sorkin (Ed.), Variations on a Theme Park: The New American City and the End of Public Space (pp. 88-97). New York: The Noonday Press.

Dennis, C., Marsland, D., \& Cockett, T. (2002). Central place practice: Shopping centre attractiveness measures, hinterland boundaries and the UK retail hierarchy. Journal of Retailing \& Consumer Services, 9, 185-199. DOI: 10.1016/S0969-6989(01)00021-2.

Dennis, C., Marsland, D., \& Newman, A. (2005). Objects of desire: Consumer behaviour in shopping centre choices. Hampshire/New York: Palgrave MacMillan.

Dobson, J. (2015). Britain's town centres: From resilience to transition. Journal of Urban Regeneration and Renewal, 8, 347-355.

Duranton, G., \& Puga, D. (2000). Diversity and specialisation in cities: Why, where and when does it matter? Urban Studies, 37, 533-555. DOI: 10.1080/0042098002104.

Erkip, F., Kizilgün, Ö, \& Akinci, G.M. (2014). Retailers' resilience strategies and their impacts on urban spaces in turkey. Cities, 36, 112-120. DOI:

10.1016/j.cities.2012.12.003.

Fornell, C., \& Larcker, D.F. (1981). Evaluating structural equation models with unobservable variables and measurement error. Journal of Marketing Research, 18, 39-40. DOI: $10.2307 / 3151312$.

Garate, S., \& Pennington-Cross, A. (2014). Measuring the impact of agglomeration on productivity: Evidence from chilean retailers. Urban Studies, 51, 1653-1671. DOI: 10.1177/0042098013499797.

Glancey, J. (2014). The death of the US shopping mall. Retrieved September/04, 2016, from http://www.bbc.com/culture/story/20140411-is-the-shopping-mall-dead 
Grant, D.B., Teller, C., \& Teller, W. (2005). 'Hidden' opportunities and benefits in using web-based business-to-business surveys. International Journal of Market Research, 47, 641-666. DOI: 1470-7853.

Grant, R.M. (1991). The resource-based theory of competitive advantage: Implications for strategy formulation. California Management Review, 33, 114-135. DOI: $10.2307 / 41166664$.

Guy, C. (2007). Planning for retail development. London: Routledge.

Hair Jr, J.F., Black, W.C., Babin, B.J., \& Anderson, R.E. (2013). Multivariate data analysis. Upper Saddle River/NJ: Pearson.

Hanlon, B. (2008). The decline of older, inner suburbs in metropolitan america. Housing Policy Debate, 19, 423-456. DOI: 10.1080/10511482.2008.9521642.

Hardwick, J.M. (2004). Mall maker. Victor Gruen, architect of an American dream. Pennsylvania: University of Pennsylvania Press.

Hart, C., Stachow, G., \& Cadogan, J.W. (2013). Conceptualising town centre image and the customer experience. Journal of Marketing Management, 29, 1753-1781. DOI: 10.1080/0267257X.2013.800900.

Haytko, D.L. (2004). It's all at the mall: Exploring adolescent girls' experiences. Journal of Retailing, 80, 67-83. DOI: 10.1016/j.jretai.2004.01.005.

Hu, L., \& Bentler, P.M. (1998). Fit indices in covariance structure modelling: Sensitivity to underparameterized model misspecification. Psychological Methods, 3, 424-453. DOI: 10.1037//1082-989X.3.4.424.

Hu, L., \& Bentler, P.M. (1999). Cutoff criteria for fit indexes in covariance structure analysis: Conventional criteria versus new alternatives. Structural Equation Modeling, 6, 1-55. DOI: 10.1080/10705519909540118.

Hughes, C., \& Jackson, C. (2015). Death of the high street: Identification, prevention, reinvention. Regional Studies, Regional Science, 2, 237-256. DOI: 10.1080/21681376.2015.1016098.

Ilieva, J., Baron, S., \& Healey, M.N. (2002). Online surveys in marketing research: Pros and cons. International Journal of Market Research, 44, 361-376. DOI: 1470-7853. 
Kaplan, D. (2008). Structural equation modeling. foundation and extensions. Thousand Oaks (CA), London, New Delhi: Sage Publications.

Knoben, J., \& Oerlemans, L.A.G. (2006). Proximity and inter-organizational collaboration: A literature review. International Journal of Management Reviews, 8, 71-89. DOI: 10.1111/j.1468-2370.2006.00121.x.

Križan, F., Bilková, K., \& Kita, P. (2014). Urban retail market in Bratislava (Slovakia): Consumers perception and classification of shopping centres. Management \& Marketing. Challenges for the Knowledge Society, 9, 483-500.

Lavie, D. (2006). The competitive advantage of interconnected firms: An extension of the resource-based view. Academy of Management Review, 31, 638-658. DOI: 10.5465/AMR.2006.21318922.

Leszczyc, P.T.L.P., Sinha, A., \& Sahgal, A. (2004). The effect of multi-purpose shopping on pricing and location strategy for grocery stores. Journal of Retailing, 80, 85-99. DOI: 10.1016/j.jretai.2004.04.006.

Longstreth, R.W. (1998). City center to regional mall: Architecture, the automobile, and retailing in Los Angeles, 1920-1950

. Cambridge: MIT Press.

Lowe, M.S. (2000). Britain's regional shopping centres: New urban forms? Urban Studies, 37, 261-274. DOI: 10.1080/0042098002186.

Michon, R., Chebat, J.C., \& Turley, L.W. (2005). Mall atmospherics: The interaction effects of the mall environment on shopping behavior. Journal of Business Research, 58, 576583. DOI: 10.1016/j.jbusres.2003.07.004.

Möller, K., \& Rajala, A. (2007). Rise of strategic nets - new modes of value creation. Industrial Marketing Management, 36, 895-908. DOI: 10.1016/j.indmarman.2007.05.016.

Oppewal, H., \& Holyoake, B. (2004). Bundling and retail agglomeration effects on shopping behavior. Journal of Retailing and Consumer Services, 11, 61-74. DOI: 10.1016/S09696989(02)00079-6.

Ozuduru, B.H., Varol, C., \& Yalciner Ercoskun, O. (2014). Do shopping centers abate the resilience of shopping streets? The co-existence of both shopping venues in Ankara, Turkey. Cities, 36, 145-157. DOI: 10.1016/j.cities.2012.10.003. 
Pan, Y., \& Zinkhan, G.M. (2006). Determinants of retail patronage: A meta-analytical perspective. Journal of Retailing, 82, 229-243. DOI: 10.1016/j.jretai.2005.11.008.

Reimers, V. (2013). Convenience for the car-borne shopper: Are malls and shopping strips driving customers away? Transportation Research Part A: Policy and Practice, 49, 35 47. DOI: 10.1016/j.tra.2013.01.002.

Reimers, V., \& Clulow, V. (2004). Retail concentration: A comparison of spatial convenience in shopping strips and shopping centres. Journal of Retailing and Consumer Services, 11, 207-221. DOI: 10.1016/S0969-6989(03)00038-9.

Ruiz, J.P., Chebat, J.C., \& Hansen, P. (2004). Another trip to the mall: A segmentation study of customers based on their activities. Journal of Retailing and Consumer Services, 11, 333-350. DOI: 10.1016/j.jretconser.2003.

Schwartz, N. (2015). The economics (and nostalgia) of dead malls. The New York Times, Jan 3.

Severin, V., Louviere, J.J., \& Finn, A. (2001). The stability of retail shopping choices over time and across countries. Journal of Retailing, 77, 185-202. DOI: 10.1016/S00224359(01)00043-4.

Simmie, J., \& Martin, R. (2010). The economic resilience of regions: Towards an evolutionary approach. Cambridge Journal of Regions, Economy and Society, 3, 27-43. DOI: $10.1093 /$ cjres/rsp029.

Steenkamp, J.B., \& Baumgartner, H. (1998). Assessing measurement invariance in crossnational consumer research. Journal of Consumer Research, 25, 78-90. DOI: $10.1086 / 209528$.

Teller, C. (2008). Shopping streets versus shopping malls - determinants of agglomeration format attractiveness from the consumers' point of view. International Review of Retail, Distribution \& Consumer Research, 18, 381-403. DOI: 10.1080/09593960802299452.

Teller, C., Alexander, A., \& Floh, A. (2016). The impact of competition and cooperation on the performance of a retail agglomeration and its stores. Industrial Marketing Management, 52, 6-17. DOI: 10.1016/j.indmarman.2015.07.010.

Teller, C., \& Dennis, C. (2012). The effect of ambient scent on consumers' perception, emotions and behaviour: A critical review. Journal of Marketing Management, 28, 1436. DOI: 10.1080/0267257X.2011.560719. 
Teller, C., \& Reutterer, T. (2008). The evolving concept of retail attractiveness: What makes retail agglomerations attractive when customers shop at them? Journal of Retailing and Consumer Services, 15, 127-143. DOI: 10.1016/j.jretconser.2007.03.003.

Teller, C., \& Schnedlitz, P. (2012). Drivers of agglomeration effects in retailing: The shopping mall tenant's perspective. Journal of Marketing Management, 28, 1043-1061. DOI: 10.1080/0267257X.2011.617708.

Thomas, C.J., \& Bromley, R.D.F. (1993). The impact of out-of-centre retailing. In R. D. F. Bromley, \& C. J. Thomas (Eds.), Retail Change, Contemporary Issues (pp. 126-152). London: UCL Press Ltd.

Thomas, C.J., \& Bromley, R.D.F. (2002). The changing competitive relationship between small town centres and out-of-town retailing: Town revival in south wales. Urban Studies, 39, 791-817. DOI: 10.1080/00420980220119570.

Thomas, C.J., Bromley, R.D., \& Tallon, A.R. (2004). Retail parks revisited: A growing competitive threat to traditional shopping centres? Environment and Planning A, 36, 647-666. DOI: 10.1068/a3683.

Tsai, S. (2010). Shopping mall management and entertainment experience: A cross-regional investigation. Service Industries Journal, 30, 321-337. DOI: $10.1080 / 02642060802123376$.

Turley, L.W., \& Milliman, R.E. (2000). Atmospheric effects on shopping behavior: A review of the experimental evidence. Journal of Business Research, 49, 193-211. DOI: 10.1016/S0148-2963(99)00010-7.

van der Krabben, E. (2009). Retail development in the Netherlands: Evaluating the effects of radical changes in planning policy. European Planning Studies, 17, 1029-1048. DOI: $10.1080 / 09654310902949596$.

Van der Waerden, P., Borgers, A., \& Timmermans, H.J.P. (1998). The impact of the parking situation in shopping centres on store choice behaviour. GeoJournal, 45, 309-315. DOI: 10.1023/A:1006987900394.

Van Kenhove, P., de Wulf, K., \& van Waterschoot, W. (1999). The impact of task definition on store-attribute saliences and store choice. Journal of Retailing, 75, 125-137. DOI: 10.1016/S0022-4359(99)80007-4. 
Vogel, V., Evanschitzky, H., \& Ramaseshan, B. (2008). Customer equity drivers and future sales. Journal of Marketing, 72, 98-108. DOI: 10.1509/jmkg.72.6.98.

Vorhies, D.W., \& Morgan, N.A. (2005). Benchmarking marketing capabilities for sustainable competitive advantage. Journal of Marketing, 69, 80-94.

Wahlberg, O. (2016). Small town centre attractiveness: Evidence from Sweden. International Journal of Retail \& Distribution Management, 44, 465-488. DOI: 10.1108/IJRDM-082014-0121.

Warnaby, G., Bennison, D., \& Davies, B.J. (2005). Marketing town centres: Retailing and town centre management. Local Economy, 20, 183-204. DOI:

$10.1080 / 13575270500053282$.

Weltevreden, J.W.J., \& Atzema, O.A.L.C. (2006). Cyberspace meets high street: Adoption of click-and-mortar strategies by retail outlets in city centers. Urban Geography, 27, 628650. DOI: 10.2747/0272-3638.27.7.628.

Wood, S., Lowe, M., \& Wrigley, N. (2010). Conceptualising innovative customer-facing responses to planning regulation: The UK food retailers. The Service Industries Journal, 30, 1967-1990. DOI: 10.1080/02642060903191124.

Wood, S., \& Reynolds, J. (2013). Knowledge management, organisational learning and memory in UK retail network planning. The Service Industries Journal, 33, 150-170. DOI: $10.1080 / 02642069.2011 .614340$.

Wrigley, N., \& Dolega, L. (2011). Resilience, fragility, and adaptation: New evidence on the performance of UK high streets during global economic crisis and its policy implications. Environment and Planning A, 43, 2337-2363. DOI: 10.1068/a44270.

Wrigley, N., \& Lambiri, D. (2014). High street performance and evolution: A brief guide to the evidence, july 2014. University of Southampton, UK:

Wrigley, N., Lambiri, D., Astbury, G., Dolega, L., Hart, C., Reeves, C., Thurstain-Goodwin, M., \& Wood, S. (2015). British high streets: From crisis to recovery? A comprehensive review of the evidence. Southampton: University of Southampton/Economic and Social Research Council (ESRC).

Zhuang, G., Tsang, A.S.L., Zhou, N., Li, F., \& Nicholls, J.A.F. (2006). Impacts of situational factors on buying decisions in shopping malls. European Journal of Marketing, 40, 1743. DOI: 10.1108/03090560610637293. 
Appendix. Measurement models and local fit measures

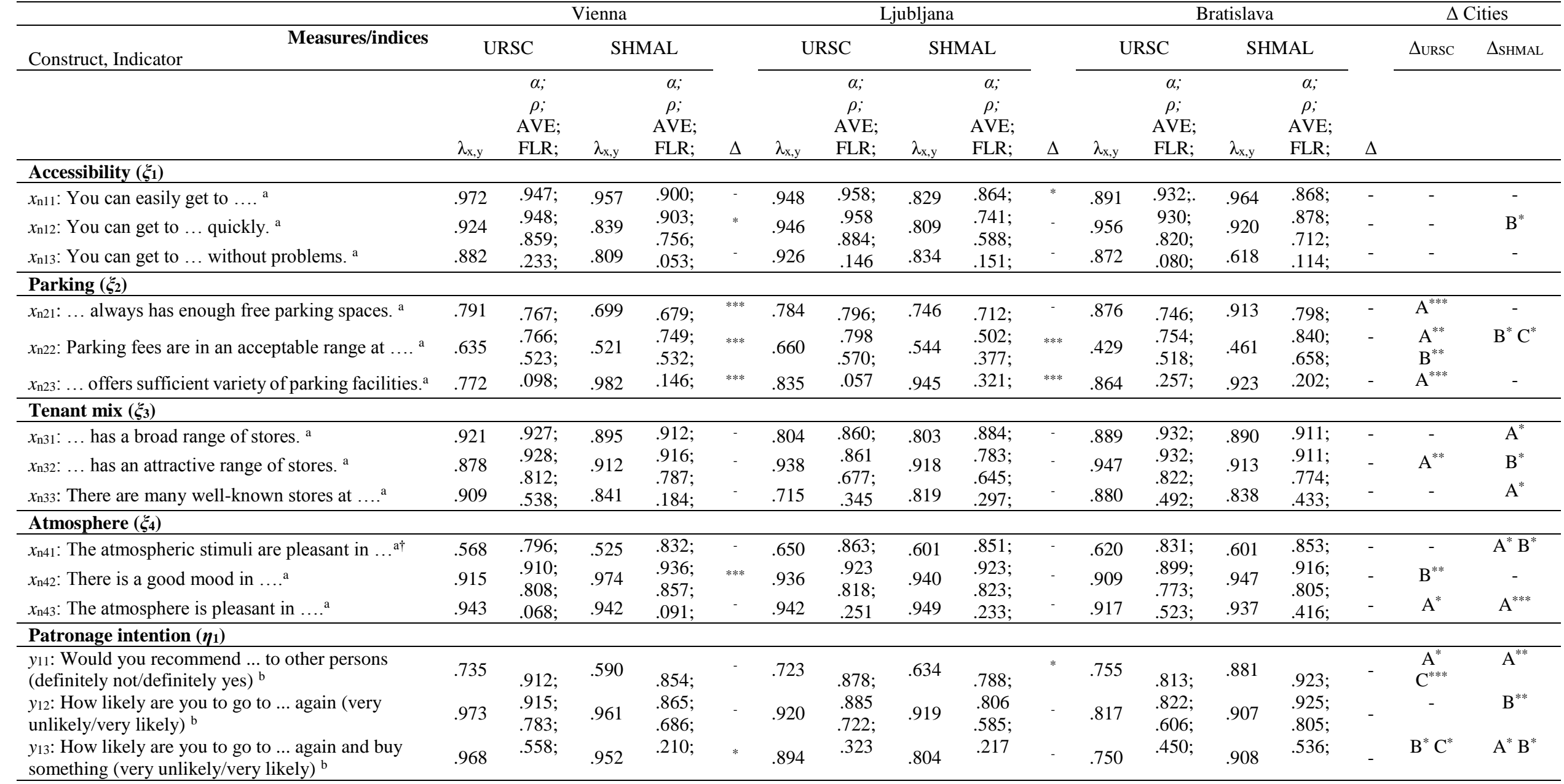

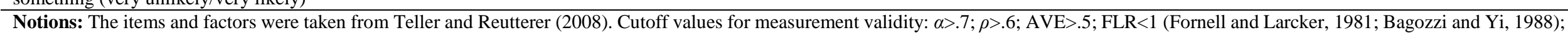

Caption: $\mu$, mean value; $\sigma$, standard deviation; $\alpha$, Cronbach's alpha; $\rho$, composite reliability; AVE, average variance extracted; FLR, Fornell-Larcker ratio; ${ }^{\text {a }}$, seven-point rating scale (anchors 0-6; totally disagree - totally agree); ${ }^{\mathrm{b}}$, ten-point rating scale (anchors 0 and 9 ); ${ }^{\dagger}$, item $\mathrm{x} 41$ represents a derived measure that comprise the highly correlated high correlation between indicators $(r>.85$ )

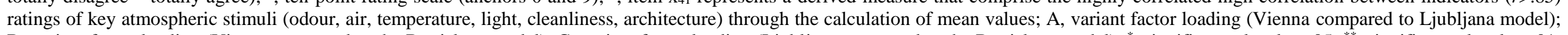

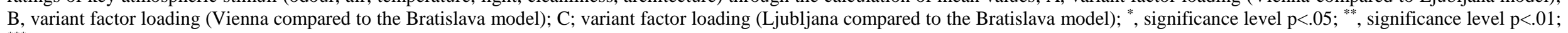

***, significance level $\mathrm{p}<.001$ 